\title{
Evaluation of Glycerin as Preserving Agent of Chicken Serum for Plate Agglutination Test
}

http://dx.doi.org/10.1590/1516-635x1603329-332

Technical Note

\section{-Author(s)}

Freitas ES de

Soldá A'

Calegari DL'

Munaretto $\mathrm{FC}^{\prime}$

Dietrich GF

Back $A^{\prime}$

MercoLab Laboratórios Ltda

Rua Maringá, 2388, São Cristovão, Cascavel-PR, Caixa Postal 4040, CEP 85816-280

\section{Mail Address}

Corresponding author e-mail address: MercoLab Laboratórios Ltda

Rua Maringá, 2388, São Cristovão, Cascavel-PR, Caixa Postal 4040, CEP 85816-280

E-mail: sorologia@mercolab.com.br

\section{nKeywords}

Seroagglutination, glycerol, preservation, refrigeration, shelf life.

\section{ABSTRACT}

Serum is widely used for the purpose of monitoring and diagnosis support for most of poultry diseases. In the case of the serum plate agglutination test (SPA), commonly used to detect antibodies for Salmonella Pullorum (SP), Mycoplasma gallisepticum (MG) and Mycoplasma synoviae (MS), serum cannot be frozen because it may result in false positive. Without freezing, serum can last only for a few days. In this experiment, glycerin was evaluated as a serum preservering agent. About 50 samples for each disease and analyzed by SPA test previously were separated. Glycerin was added to serum from commercial chickens, with and without antibodies for SP, MG and $M S$, in the proportion of 1:1 (serum:glycerin) and kept at refrigerated conditions $\left(2\right.$ to $\left.8{ }^{\circ} \mathrm{C}\right)$. For four years they were tested by the SPA, initially weekly, afterward monthly and then annually. The results show that serum with glycerin give consistent and valid results according to the kind of antibodies present for the period tested. Sera that glycerin was not added to, the results were valid only for the first week. From the second week on, microbial growth affected the test results of the sera without glycerin. Our investigation shows that glycerin can be used to preserve chicken serum for SPA under refrigerated conditions. It is an easy, simple and cheap procedure that can extend serum shelf life, useful mainly for control sera.

\section{INTRODUCTION}

Serology is a laboratory method of analysis which aims to study the antigen-antibody reactions. Serum is routinely used to detect and/or evaluate its level of antibodies by an antigen. For its evaluation, both must be specific and homologous (Santos, 2009). Nowadays, this detection can be performed by various techniques, the most commonly used are ELISA (Enzyme-linked immunosorbent assay), HI (hemagglutination inhibition), AGP (agar gel precipitin), SN (seroneutralization), SAT (slow seroagglutination test) and SPA (serum plate agglutination test).

When using the SPA technique the antibody primarily detected is IgM, followed by medium-high titers of IgG (Back \& Ishizuka, 2010). The SPA is a qualitative test with good sensitivity, but not with as good specificity. It is widely used for screening, monitoring and controlling typhoid Salmonella and Mycoplasmosis in poultry (Santos, 2009; Cardoso, 2009). However, for a definitive positive serologic diagnosis, it is necessary to perform a confirmatory test such as HI or ELISA (Back, 2010; I.N. MAPA 44/2001).

One of the limitations of the SPA is the sera preservation. It cannot be frozen because it may result in false positive due to a precipitation of some proteins and at refrigerated temperatures it remains viable only for a few days (Hay \& Westwood, 2002). Glycerin has been used in 
human and veterinary medicine for the preservation of different cell types (Alvarenga, 1992; Batista et al. 1996; Daleck et al. 1987; Mota et al. 2002; Nolasco et al. 2003; Pigossi, 1964; Pigossi, 1967; Reyes, 1993), microorganisms (Hubálek, 2003) and blood serum (Bier, 1982; Hay \& Westwood, 2002). Its main advantages are low cost, antiseptic property, texture cell preservation, increase in strength without altering the degree of cell elasticity, facilitates handling and keeps its antigenicity properties (Alvarenga, 1992; Miller, 1972; Pigossi, 1964; Pigossi, 1967; Batista et al. 1996; Daleck et al., 1987; Mota et al., 2002; Nolasco et al. 2003; Reyes, 1993). Miller (1972) adopted the preservation of cells (bacteria) in glycerol at $-20^{\circ} \mathrm{C}$ for years. However, so far, there is no description of sera from birds preserved in glycerin at refrigerated conditions $\left(2-8^{\circ} \mathrm{C}\right)$ while maintaining its antigen-antibody reaction properties without undesired reactions.

This investigation aimed at evaluating the preservation of poultry sera used as control in SPA tests when kept refrigerated in glycerin at $2-8^{\circ} \mathrm{C}$.

\section{MATERIALS AND METHODS}

The present study was carried out at the serology Department of MercoLab Laboratory (Cascavel-PR, Brazil) from January 2010 to December 2013. The analyses were performed with poultry sera from commercial chickens (in nature) by the SPA test which is used to evaluate the presence of antibodies for Mycoplasma synoviae (MS), Mycoplasma gallisepticum (MG) and Salmonella Pullorum (SP).

About 50 positive and negative samples for each disease and analyzed by SPA test previously were separated and pooled. Each pool was divided into two fractions. One of $10 \mathrm{~mL}$ and the other of $5 \mathrm{~mL}$. The fractions of $5 \mathrm{ml}$ were added to $5 \mathrm{ml}$ of neutral liquid glycerin, distilled twice (ratio of glycerin:serum was 1:1). No glycerin was added to the serum fraction of $10 \mathrm{ml}$. Each fraction, with and without glycerin, was subdivided into 20 aliquots of $0.5 \mathrm{ml}$ each in eppendorf tubes and kept under refrigeration at $2-8{ }^{\circ} \mathrm{C}$.

Sera were evaluated weekly for two weeks in January and monthly from February to December of 2010. In 2011 the samples were tested quarterly (Table 1). From then on, sera were evaluated annually. For all tests, commercial antigens were used for MS, MG e SP.

Serum and antigen were removed from the refrigerator and left at room temperature for one hour before being tested. Equal amounts $(30 \mu \mathrm{l})$ of antigen and serum were pipetted and homogenized in a big dropon in a glass plate, and rotated several times. The reading was performed after two minutes of the initial homogenization. The interpretation was based on the presence or absence of agglutination (small clots). Sera which agglutinated were considered positive and those with no agglutination were considered negative. The temperature of the test room was kept between 21 and $25^{\circ} \mathrm{C}$. All the test procedures described followed the manufacturer's specifications and general recommendations from Brazilian Ministry of Agriculture (MAPA) (BRASIL, 1995; BRASIL, 1994).

\section{RESULTS AND DISCUSSION}

Several methods and substances have been used to preserve cells, tissue and serum, such as low temperature $\left(-20^{\circ} \mathrm{C}\right.$ and $\left.-80^{\circ} \mathrm{C}\right)$, lyophilization, mineral oil and cryopreservation. Preservation of microorganisms and tissues in glycerol has been used in laboratories worldwide, and meets most of the desirable characteristics of a good preservation method. In the case of poultry serum, antimicrobial agents such as sodium azide and thimerosal have been used for preservation, but the results have not always been satisfactory in our experience. Frequently, bacteria growth has been observed, invalidating the results.

The results of our investigation are shown in Table 1. In the first two trails, 1 and 7 days post refrigeration, the results of agglutination for MG, MS and SP showed no difference in serum with and without glycerin. All the positive serum presented results of agglutination and the negative control sera remained non-reactive, as expected. These results demonstrate that serum can be kept fresh at refrigerated temperatures (2-8 ${ }^{\circ} \mathrm{C}$ ) for a week without affecting the results. It is known that this can vary depending on the degree of the bacterial contamination of the sera, which is related to the hygienic harvesting and handling of the samples (Personal communication). From day 14 on, in spite of the serum being kept at $\left(2-8^{\circ} \mathrm{C}\right)$, samples that did not have glycerin (in nature) added to it were inappropriate for analysis. They presented cloudy appearance (indicating microbial growth) and were discarded. The investigation continued only with the serum with glycerin, showing no evidence of microbialgrowth (transparent), demonstrating its property of preservation (antiseptic), as described by Alvarenga (1992).

According to MAPA (BRASIL, 1995; BRASIL, 1994) poultry sera for analysis must be refrigerated and processed until 3 days after the harvest. After this time, 
Table 1 - Results of SPA test using sera stored under refrigeration with or without glycerin for a period of four years (2010 and 2013).

\begin{tabular}{|c|c|c|c|c|c|c|c|c|}
\hline \multirow[t]{2}{*}{ Period } & \multicolumn{4}{|c|}{ Serum without glycerin } & \multicolumn{4}{|c|}{ Serum with glycerin } \\
\hline & $M G(+)$ & $\mathrm{MS}(+)$ & $\mathrm{SP}(+)$ & $C(-)$ & $M G(+)$ & $\mathrm{MS}(+)$ & $\mathrm{SP}(+)$ & $C(-)$ \\
\hline January/2010 - day 1 & + & + & + & - & + & + & + & - \\
\hline January/2010 - day 7 & + & + & + & - & + & + & + & - \\
\hline January/2010 - day 14 & * & * & * & * & + & + & + & - \\
\hline February/2010 & * & * & * & * & + & + & + & - \\
\hline March/2010 & * & * & * & * & + & + & + & - \\
\hline April/2010 & * & * & * & * & + & + & + & - \\
\hline May /2010 & * & * & * & * & + & + & + & - \\
\hline June/2010 & * & * & * & * & + & + & + & - \\
\hline July/2010 & * & * & * & * & + & + & + & - \\
\hline August/2010 & * & * & * & * & + & + & + & - \\
\hline September/2010 & * & * & * & * & + & + & + & - \\
\hline October/2010 & * & * & * & * & + & + & + & - \\
\hline November/2010 & * & * & * & * & + & + & + & - \\
\hline December/2010 & * & * & * & * & + & + & + & - \\
\hline March/2011 & * & * & * & * & + & + & + & - \\
\hline June/2011 & * & * & * & * & + & + & + & - \\
\hline September/2011 & * & * & * & * & + & + & + & - \\
\hline December/2011 & * & * & * & * & + & + & + & - \\
\hline December/2012 & * & * & * & * & + & + & + & - \\
\hline December/2013 & * & * & * & * & + & + & + & - \\
\hline
\end{tabular}

(MG +): Mycoplasma gallisepticum positive; (MS +): Mycoplasma synoviae positive; (SP +): Salmonella Pullorum positive; (C-): Negative control; ( $\left.{ }^{\star}\right)$ : discarded.

sera should be frozen $\left(-20^{\circ} \mathrm{C}\right)$. Under manufacturer's specifications, no serum can be frozen for SPA testing, because it can lead to nonspecific reactions. This represents a limitation in the serum storage.

In the second year of evaluation (2011), the sera with glycerin were tested quarterly e in the third year on, annually, and the results were the same. These sera are still stored under refrigerated conditions $\left(2{ }^{\circ} \mathrm{C}\right.$ to 8 $\left.{ }^{\circ} \mathrm{C}\right)$ for subsequent studies.

These results demonstrate that the use of glycerin in the serum, in the proportion of 1:1, is an alternative to preserve its SPA test properties for at least two years under refrigerated conditions. Therefore, this technique for its simplicity and low cost can be used routinely in laboratories to preserve serum. It becomes very important to preserve control sera for the routine testing. Under present refrigerated conditions, it does not last more than weeks without glycerin.

\section{CONCLUSIONS}

The results of our study showed that the serum with glycerin (1:1) under refrigerated conditions $\left(2{ }^{\circ} \mathrm{C}\right.$ to $8{ }^{\circ} \mathrm{C}$ ) can keep its initial reacting properties for four years for the SPA test, whereas serum without glycerin remain viable for a week.

This is an easy, low cost and simple procedure that can be widely used to preserve chicken serum for the SPA test. Its properties to inhibit bacterial growth can be used for any chicken serum that will be tested; however, it becomes especially important to extend shelf life of control serum that is needed in every testing. Good hygiene in the sera harvest can also added to longer preservation.

\section{REFERENCES}

Alvarenga J. Possibilidades e limitações da utilização de membranas biológicas preservadas em cirurgia. In: Daleck, CR, Baptista LC, Mukai LS (Ed.). Tópicos em cirurgia de cães e gatos; 1992; Jaboticabal, SP: Funep-Unesp: 1992. p. 33-42

Back A, Ishizuka MM. Micoplasmose aviária. In Principais doenças de notificação obrigatória da Organização Mundial de Saúde animal; 2010; São Paulo, SP; Fundação Cargill; 2010. p. 190-238.

Back A. Micoplasmose. In: . Manual de doenças de aves; 2010; Cafelândia, PR; Editora Integração; 2010. p. 157-170.

Batista LC, Daleck CR, Shimano AC, Alessi AC, Abrahão MS. Estudo comparativo da resistência à tração do peritônio (bovino, eqüino, suíno e canino) a fresco e conservado em glicerina. Brazilian Journal of Veterinary Research and Animal Science 1996; 33: 305-312. 
Bier O. Técnicas imumológicas. In Bacteriologia e imunulogia em suas aplicações à medicina e à higiene; 1982; SP; Melhoramentos; 1982. p. 870-918.

Cardoso B. Sorologia e interpretação. In: Revolledo L, Ferreira AJP. Patologia aviária; 2009; Barueri, SP: Manole; 2009. p.428 - 437.

Daleck CR, Daleck CLM, Gandolfi W, Alessi AC. Esofagoplastia cervical no cão com peritôneo autólogo ou homólogo conservado em glicerina "estudo experimental". Ars Veterinária 1987; 3 (2): 195-202.

Hay FC, Westwood OMR. Immunological manipulations in vivo. In: Practical Immunology; 2002, Oxford: Blackwell Science, 2002. $\overline{\text { p. } 326}$ $-345$.

Hubálek Z. Protectans used in the cryopreservation of microorganisms. Cryobiology 2003; 46:205-209.

Miller JH. Experiments in Molecular Genetics. Cold Spring Harbor Laboratory; 1972. p.466.

Ministério da Agricultura, Pecuária e Abastecimento. Instrução normativa $n^{\circ} 44$, de 23 de Agosto de 2001. Aprova normas técnicas para o controle e a certificação de núcleos e estabelecimentos avícolas para a micoplasmose aviária (Mycoplasma gallisepticum, synoviae e melleagridis). Diário Oficial União. 24 Ago 2001. Seção 1, p. 68.

Ministério da Agricultura, Pecuária e Abastecimento. Portaria n 126, de 03 de novembro de 1995. Aprova normas para credeciamento e monitoramento de laboratórios de diagnóstico das salmonelas aviárias (S. Enteritidis, S. Gallinarum, S. Pullorum e S. Typhimurium). Diário Oficial União. 6 nov 1995. Seção 1, p. 17694.
Ministério da Agricultura, Pecuária e Abastecimento. Portaria $n^{\circ} 208$ de 20 de Dezembro de 1994. Aprova normas de credenciamento e monitoramento de laboratórios de diagnóstico das micoplasmoses aviárias. Diário Oficial União. 26 dez 1994. Seção 1, p. 20510.

Mota FCD, Eurides D, Belletti ME, Freitas PMC, Mastrantonio EC, Shimizu BJ, Cardoso JR, Martins AK. Análise ultra-estrutural da túnica muscular do intestino delgado de cães preservado em diferentes meios. Brazilian Journal of Veterinary Research and Animal Science; 2002; 39 (1): 1317.

Nolasco RM, Beletti ME, Eurides D, Silva FOCE, Coelho HE, Daleck CR, Silva LAF. Avaliação histológica e ultra-estrutural de tendões de bovinos preservados em diferentes meios. Ars Veterinária, 2003; 19 (3): 210 215.

Pigossi N. A Glicerina na conservação de dura-máter: estudo experimental. [Dissertation]. São Paulo (SP). Faculdade de Medicina, Universidade de São Paulo; 1967.

Pigossi N. Implantação de dura-máter homóloga conservada em glicerina. Estudo experimental em cães. [Dissertation]. São Paulo (SP): Faculdade de Medicina, Universidade de São Paulo; 1964.

Reyes EEF. Testes físicos comparativos de membranas biológicas preservadas em glicerina, congeladas e a fresco. [Dissertation]. São Paulo (SP) Faculdade de Medicina Veterinária e Zootecnia, Universidade de São Paulo; 1993

Santos CHC. Diagnóstico microbiológico e sorológico. In: Berchieri Júnior A, Silva EN, Fábio JD, Sesti L, Zuanase MAF. Doenças das aves; 2009; Campinas, SP: Facta; 2009. p.79-102. 